\title{
Soil environment of Pulsatilla vernalis (L.) Mill. at selected sites in the Polish lowland
}

\author{
Andrzej Grzyl ${ }^{*}$, Arkadiusz Niewiadomski², Beata Woziwoda ${ }^{1}$ \\ 'Department of Geobotany and Plant Ecology, University of Łódź, Banacha 12/16, 90-237 Łódź, Poland \\ ${ }^{2}$ Department of Physical Geography, University of Łódź, Narutowicza 88, 90-139 Łódź, Poland
}

\section{Abstract}

The paper presents soil conditions of Pulsatilla vernalis in the Polish lowland. There were determined species preferences in relation to physical and chemical properties, grain size composition and the type of soil. It has been found that $P$. vernalis prefers very poor sandy, acid, dry and permeable soils, with small water capacity. The range of habitat parameters at the lowland sites differs, however, from the conditions at the mountain sites. Due to specific habitats of the species, new ecological indicator values were proposed for the lowland sites of $P$. vernalis. The results of soil analysis presented in this paper, as well as other data related to biology of the species, should be accounted for in the active protection plan, including the processes of reintroduction and introduction of the species.

Keywords: pasqueflower, relict population, rare plant, distribution, soil properties, ecological indicator values, active conservation, Poland

\section{Introduction}

Pulsatilla vernalis is a rare species in Poland [1], included in the Polish red data book [2] and on the red data list for Poland [3]. This species is under strict legal protection in Poland [4]. It represents a European-temperate sub-element from the group of Holarctic elements [5] and the Alpine-North European distribution type from the European-temperate-montane group. The "Pulsatilla vernalis distribution type" with two occurrence centers: mountain and lowland [6,7], was not included in the latest classification of geographical elements of the native flora of Poland [5]. The lowland sites were defined as connecting elements between the mountain range and the northern range [5].

$P$. vernalis frequently occurs in the alpine and subalpine zone of central and northern Europe $[1,8]$. It is very seldom in the lowlands - mostly in Central Europe $[1,9,10]$, in southern Scandinavia [11-13] and in the Russian Republic of Karelia [14], where it is regarded as a relict of the Valdai Glaciation [15]. In Austria [16] and Belarus [17], the species is considered extinct.

The disappearance of the species' lowland sites observed in the last century is also related to the theory that $P$. vernalis

* Corresponding author. Email: grzyl@biol.uni.lodz.pl

Handling Editor: Aleksandra Samecka-Cymerman

This is an Open Access digital version of the article distributed under the terms of the Creative Commons Attribution 3.0 License (creativecommons.org/licenses/by/3.0/), which permits redistribution, commercial and non-commercial, provided that the article is properly cited. occurs mainly in the mountain areas, while the lowland sites are relict ones [18]. Their presence in lowland Poland is associated with at least two independent migration routes with the origin in the western and eastern Alps [18]. Probably the former range of the species, with no strong occurrence center, split into local sites represented by isolated populations. In Poland, they are located at the eastern border of the former range of $P$. vernalis [1].

The results of contemporary chorological and population studies conducted in Poland [1], compiled with the available data covering all previous records of the species [19], confirmed the extinction of $P$. vernalis at the lowland sites. Consequently, it has been decided to change the risk category of the species from vulnerable $[2,3]$ to high risk of extinction (endangered) [20]. The main, identified threats to the pasqueflower include intensification of forestry, small size of preserved populations and no natural regeneration [1]. In these circumstances, it is necessary to undertake certain measures aiming at protection of the existing $P$. vernalis sites and successful reintroduction and introduction of this species. This involves detailed identification of the species habitat conditions, mainly the soil on which it grows.

The current description of $P$. vernalis habitat preferences in the form of ecological indicator values $[21,22]$ is inaccurate due to duality of the species habitat conditions. In the textbooks on ecology and biology of $P$. vernalis, specific habitat characteristics of montane and lowland populations were disregarded. Also plant communities (both montane and lowland) with the pasqueflower presence differ from each other. Within the mountain range, the species grows in alpine grasslands from the class of Seslerietea variae, including the association of Festuco versicoloris-Agrostietum alpinae with 
$P$. vernalis as a characteristic species [23]. In the lowland part of Poland, $P$. vernalis has a narrow phytocoenotic scale. Although it is not defined as a characteristic species [23], it is clearly associated with conifer forest communities from the alliance Dicrano-Pinion [22]. According to Wójtowicz [2], $P$. vernalis occurs in phytocoenoses similar to subcontinental mesic pine forest Peucedano-Pinetum. However, since most of the sites are located in the suboceanic climate zone, it would be more accurate to associate the occurrence of this species with the association of Leucobryo-Pinetum and its transitional forms of subcontinental mesic pine forest. This is reflected in the co-occurrence of differential species of Leucobryo-Pinetum in the communities with $P$. vernalis, including Peucedanum oreoselinum, Solidago virgaurea, Convallaria maialis and Polygonatum odoratum [24]. Coniferous communities with $P$. vernalis in Leningrad Oblast $[14,15]$ and at the lowland sites in the Scandinavian Peninsula [25] have a similar structure and species composition.

The paper has the following objectives: (i) to identify the soil conditions prevailing at the preserved, representative lowland sites of $P$. vernalis in Poland, (ii) to identify the key parameters in the process of possible reintroduction of the species, and (iii) to refine the ecological indicator values of $P$. vernalis for lowland sites.

\section{Material and methods}

A small number and small size of lowland P. vernalis populations in Poland, the anthropogenic character of habitat in majority of localities, as well as a high rate of species extinction [1] significantly restricted any representative soil studies. In the end, the research was conducted at three isolated sites: in the village of Rogowiec near Bełchatów (N: 51 $\left.{ }^{\circ} 16^{\prime} 41^{\prime \prime}, \mathrm{E}: 19^{\circ} 17^{\prime} 22^{\prime \prime}\right)$, Piskorzeniec near Przedbórz (N: 51 ${ }^{\circ} 03^{\prime} 58^{\prime \prime}$, E: $\left.20^{\circ} 00^{\prime} 14^{\prime \prime}\right)$ and

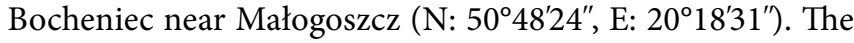
sites were considered to be most representative in terms of the size of the preserved populations and nearly natural character of coniferous forest phytocoenoses (Fig. 1a-c) in which they occur [1]. More than 350 leaf rosettes of mostly generative specimens were found at the site in Bocheniec over an area of ca. $600 \mathrm{~m}^{2}$. The population in Rogowiec consists of 220 rosettes of leaves and covers an area of ca. $500 \mathrm{~m}^{2}$. In both abovementioned populations, the recruitment of new specimens has been observed [24]. The stable population from Piskorzeniec is represented by 5 five reproductive adults (leaf rosettes) distributed over an area of $6 \mathrm{~m}^{2}$.

During the fieldwork, soil profiles were exposed (the permission to perform the only one full soil profile within each locality was obtained) and 13 samples were collected to determine certain chemical properties and grain size composition. In addition, 11 samples were collected with Kopecky's cylinders to determine physical properties (small thickness of the humus horizon in Bocheniec and Piskorzeniec, as well as loose and granular structure of the material made it impossible to collect the material for the analysis).

The following parameters were determined in the course of laboratory analysis:

(i) grain size composition according to standard Bouyoucos' method modified by Cassagrande and Prószyński;

(ii) soil reaction $\mathrm{pH}$ in $\mathrm{H}_{2} \mathrm{O}$ and $1 \mathrm{~mol} \mathrm{dm}^{-3} \mathrm{KCl}$ with the potentiometric method (the soil/solution ratio $1: 2.5$ );

(iii) carbonates content by means of Scheibler's method; (iv) content of exchangeable alkaline cations: $\mathrm{Ca}^{2+}, \mathrm{Mg}^{2+}$, $\mathrm{K}+, \mathrm{Na}+$ in $\left[\mathrm{cmol}(+) \mathrm{kg}^{-1}\right]$ according to Pallman's method, with extraction of $1 \mathrm{~mol} \mathrm{CH}_{3} \mathrm{COOCH}_{4}$;

(v) physical properties: bulk (BD) and volumetric (aVD \& tVD) density, total porosity (P), actual humidity (gAH \& vAH) and capillary water capacity (gCWC \& vCWC) according to Kopecky's method;

(vi) sorptive properties: hydrolytic acidity $(\mathrm{Ha})$ and total exchangeable bases (TEB) in $\left[\mathrm{cmol}(+) \mathrm{kg}^{-1}\right]$ according to Kappen's methods. Based on the results, also cations exchange capacity (CEC) and base saturation rank (BS) were calculated.

The nomenclature and terminology of soils were accepted after new soil taxonomy of the Polish Society of Soil Science [26]. Values of ecological numbers proposed for lowland sites were quoted according to the scale accepted in Poland by Zarzycki et al. [22].

\section{Results}

As evidenced by the research, soils of $P$. vernalis habitats at the sites in Rogowiec and Bocheniec are autogenic from the order of podzols, the type of proper podzol soils (Fig. 1d,e, Tab. 1). Two genetic horizons, ca. $50 \mathrm{~cm}$ deep and characteristic of this type of soils, were distinguished in the soil profiles: eluvial (Ees) and illuvial (Bhfe) with the process of eluviation and illuviation of humic-ferruginous compounds. The organic surface layer (A) has a thickness of up to $5 \mathrm{~cm}$. At the site in Piskorzeniec, deposits from the division of lithogenic soils were identified - the order of poorly developed soils, the type of arenosols. Their profile consists of only two horizons: accumulation (A) and parent rock (C); no other genetic horizons are developed (Fig. 1f).

All soils within the sites of $P$. vernalis were extremely sandy and each horizon was represented by the granulometric group of loose sands with a small fraction of clay (Tab. 1).

In terms of physical properties, they are classified as dry and air permeable soils, with high porosity, low moisture content and minor capillary action. Soil density at the studied sites, i.e. bulk density (BD), actual volumetric density (aVD) and temporary volumetric density (tVD) increased with the depth but shows only small deviation, and the soil porosity $(\mathrm{P})$ decreased within each soil profile (Tab. 2). Low values of the total porosity indicate significant permeability to water and leaching of nutrients into deeper soil layers. Also moisture content (gAH, vAH) and capillary water capacity (gCVC, vCVC) had very low values at the studied sites, both in relation to the total mass and the volume of soil (Tab. 2). Varied but low values of capillary water capacity of all soils and especially of A horizons (Tab. 2) are a result of small contact between soil moisture and ground water.

Values of soil pH in Rogowiec and Bocheniec in eluvial (Ees) and illuvial (Bhfe) genetic soil horizons ranged from 4.2 to 5.2 (6.2), which means that soil reaction is strongly acid and acid (Tab. 3). Higher values of the active acidity coefficient ( $\mathrm{pH}$ in $\mathrm{H}_{2} \mathrm{O}$ ) were recorded in the humus horizon - they were in the range of 5.5-6.2. Soil acidification in Piskorzeniec was even stronger and ranged from 4.1 to $4.8\left(\mathrm{pH}\right.$ in $\left.\mathrm{H}_{2} \mathrm{O}\right)$.

The analyzed soils had low but heterogeneous content of organic carbon. Its content in the humus horizon in Bocheniec was $3.89 \mathrm{~g} \mathrm{~kg}^{-1}$, in Piskorzeniec - $2.7 \mathrm{~g} \mathrm{~kg}^{-1}$, and in Rogowiec - only $1.1 \mathrm{~g} \mathrm{~kg}^{-1}$ (Tab. 3). The presence of organic carbon was recorded also in illuvial horizons -0.38 and $0.64 \mathrm{~g} \mathrm{~kg}^{-1}$ in 


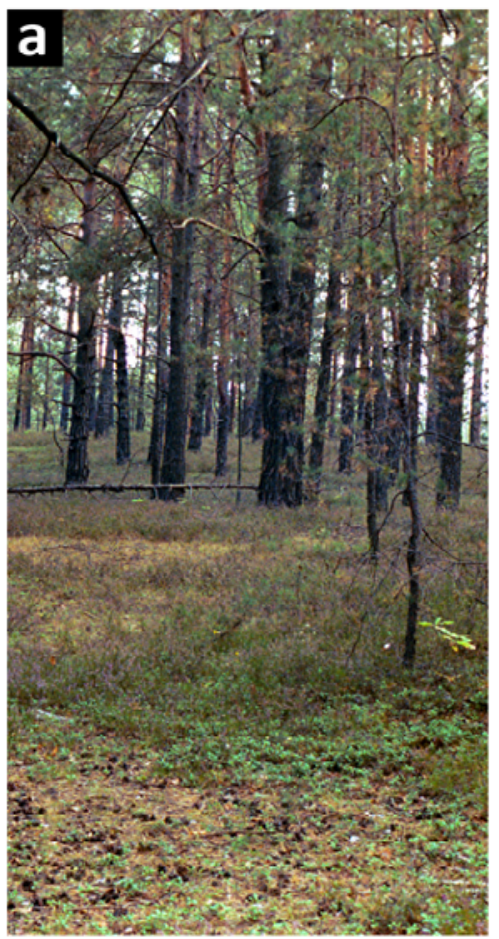

ROGOWIEC

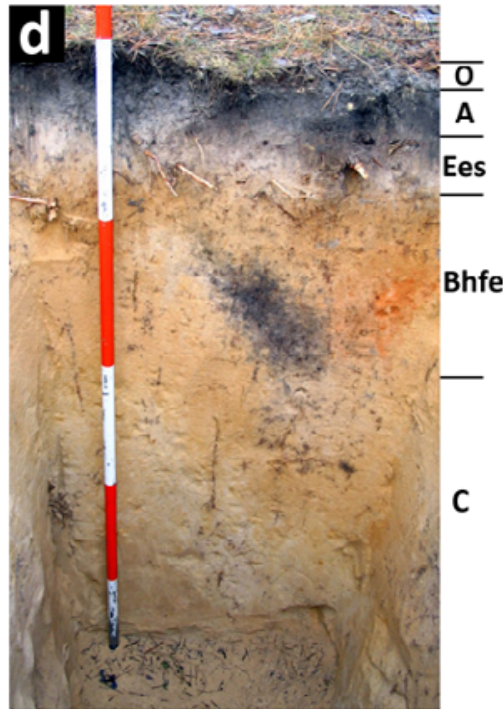

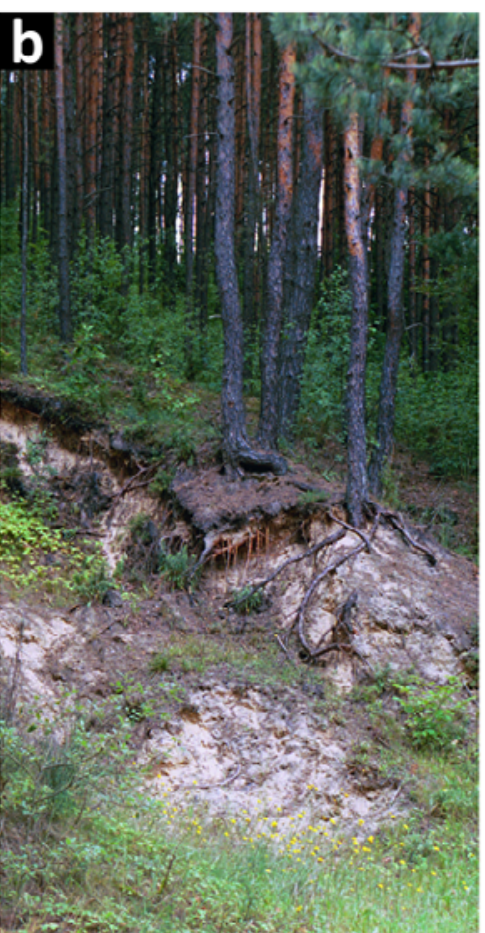

BOCHENIEC

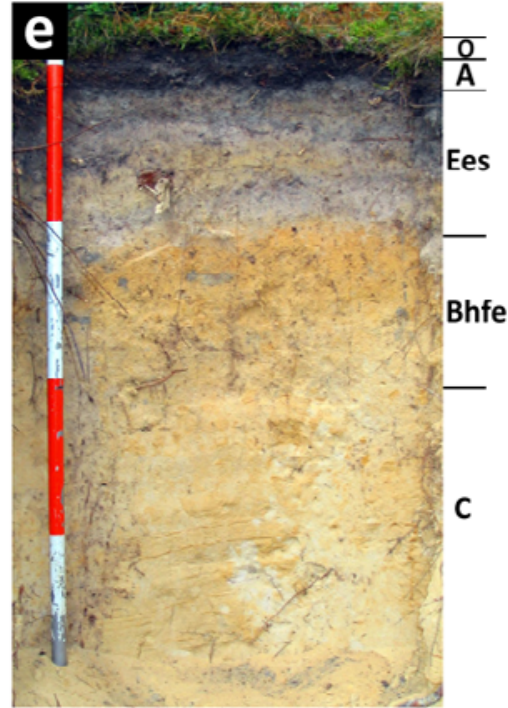

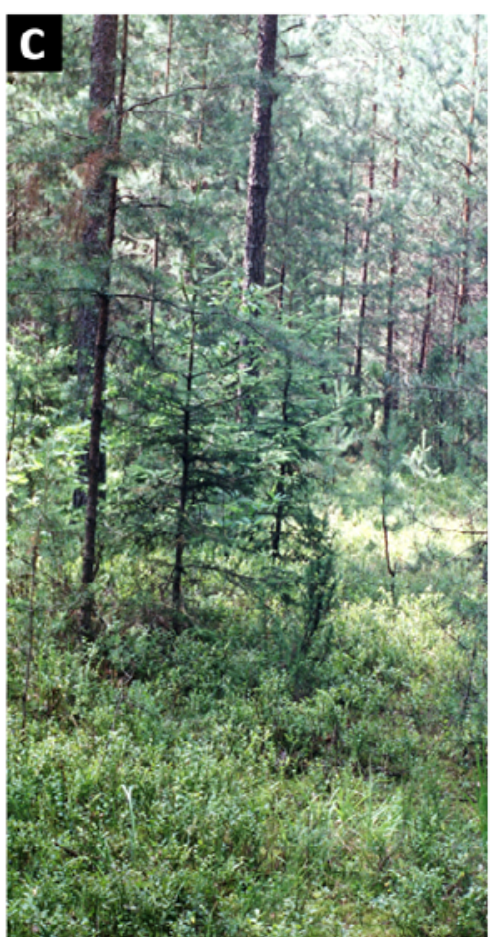

\section{PISKORZENIEC}

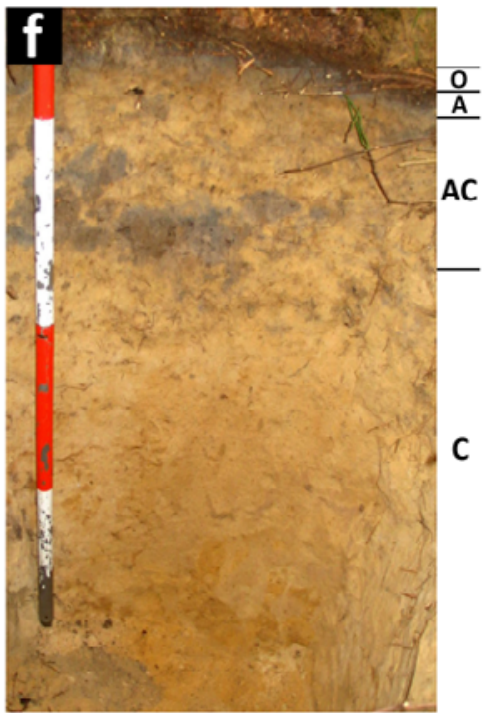

Fig. 1 Habitats and soil profiles of P. vernalis in lowland Poland. a Forest habitat on a stand in Rogowiec. b Habitat on a stand in Bocheniec. c Habitat on a stand in Piskorzeniec. d Soil profile in Rogowiec. e Soil profile in Bocheniec. f Soil profile in Piskorzeniec. Horizon symbols on soil profiles: A - topsoil; AC - mixed horizon consisting of surface soil and parent rock; Bhfe - spodic horizon with illuviation of humic and ferruginous compounds; $\mathrm{C}$ - parent rock; Ees - albic horizon; $\mathrm{O}$ - organic matter.

Rogowiec and Bocheniec, and in the mixed horizon $(\mathrm{A}-\mathrm{C})$ at the site of Piskorzeniec (Tab. 3).

The soil profiles were characterized by a low content of calcium, magnesium, sodium and potassium cations (Tab. 3). The largest resources of exchangeable cations throughout the soil profile were determined at the site in Bocheniec, and the lowest - in Piskorzeniec. Similarly, the biggest differences in the content of $\mathrm{Ca}^{+2}$ (which showed the highest variation among the analyzed elements), $\mathrm{Na}^{+}$and $\mathrm{K}^{+}$in the A-horizon and lower soil horizons were recorded at the site in Bocheniec, the smallest - in Piskorzeniec. The content of $\mathrm{Mg}^{2+}$ in the surface horizon was similar in Rogowiec and Bocheniec, and three times lower in Piskorzeniec. Abundance of cations showed very small deviation in all profiles (Tab. 3).

\section{Discussion and conclusions}

Differences in the soil conditions of $P$. vernalis at the lowland and mountain sites

As evidenced by the analysis of $P$. vernalis soil environment, there are differences in the abundance and properties of the species habitats in lowland Poland compared to mountain habitats. In the Tatras soils, it is hydrolytic acidity that mostly determines the presence of acid substances in the sorption complex [26]. The average content of alkaline cations recorded in the mountain soils is similar to their content in the studied soils of lowland Poland (cf. [27] and Tab. 3). A similar situation is observed with the base-cation saturation ratio of the 
Tab. 1 Grain size distribution of soils within sites of P. vernalis.

\begin{tabular}{|c|c|c|c|c|c|c|c|c|c|c|c|c|}
\hline \multirow[b]{2}{*}{ Profile } & \multirow{2}{*}{$\begin{array}{c}\text { Soil } \\
\text { horizon }\end{array}$} & \multirow{2}{*}{$\begin{array}{c}\text { Layer } \\
\text { thickness }\end{array}$} & \multirow{2}{*}{$\begin{array}{l}\text { Sampling } \\
\text { depth }\end{array}$} & \multicolumn{9}{|c|}{ Fraction content (\%) } \\
\hline & & & & $2.0-1.0$ & $1.0-0.5$ & $0.5-0.25$ & $0.25-0.1$ & $0.1-0.05$ & $0.05-0.02$ & $0.02-0.006$ & $0.006-0.002$ & $<0.002$ \\
\hline \multirow{4}{*}{ 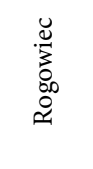 } & A & $0-5$ & $0-5$ & 6 & 18 & 42 & 25 & 4 & 2 & 1 & 1 & 1 \\
\hline & Ees & $5-20$ & $10-15$ & 8 & 11 & 45 & 30 & 3 & 1 & 0 & 1 & 1 \\
\hline & Bhfe & $20-55$ & $35-40$ & 1 & 12 & 48 & 35 & 2 & 1 & 0 & 0 & 1 \\
\hline & $\mathrm{C}$ & $55-110$ & $75-80$ & 4 & 22 & 47 & 27 & 0 & 0 & 0 & 0 & 0 \\
\hline \multirow{5}{*}{ 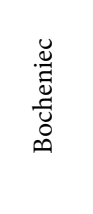 } & A & $0-5$ & $0-5$ & 6 & 16 & 30 & 31 & 12 & 3 & 0 & 1 & 1 \\
\hline & Ees & $5-30$ & $10-15$ & 2 & 7 & 26 & 46 & 15 & 2 & 0 & 1 & 1 \\
\hline & & & $23-88$ & 2 & 6 & 28 & 48 & 13 & 1 & 0 & 0 & 2 \\
\hline & Bhfe & $30-50$ & $35-40$ & 1 & 5 & 30 & 52 & 9 & 1 & 0 & 1 & 1 \\
\hline & $\mathrm{C}$ & $50-105$ & $70-75$ & 3 & 8 & 34 & 45 & 7 & 0 & 1 & 1 & 1 \\
\hline \multirow{4}{*}{ 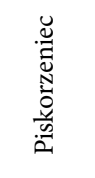 } & A & $0-2$ & $0-2$ & 4 & 23 & 35 & 24 & 7 & 3 & 2 & 1 & 1 \\
\hline & $\mathrm{AC}$ & $2-20$ & $10-15$ & 5 & 13 & 35 & 33 & 7 & 3 & 1 & 1 & 2 \\
\hline & $\mathrm{C}$ & $20-100$ & $25-30$ & 5 & 19 & 36 & 27 & 6 & 3 & 2 & 1 & 1 \\
\hline & & & $70-75$ & 5 & 12 & 32 & 42 & 4 & 2 & 1 & 1 & 1 \\
\hline
\end{tabular}

Tab. 2 Physical properties of soils within sites of P. vernalis.

\begin{tabular}{|c|c|c|c|c|c|c|c|c|c|}
\hline \multirow[b]{2}{*}{ Profile } & \multirow[b]{2}{*}{ Soil Horizon } & \multicolumn{8}{|c|}{ Physical properties } \\
\hline & & BD & aVD & tVD & $\mathbf{P}$ & gAH & vAH & gCVC & $\mathrm{vCVC}$ \\
\hline \multirow{4}{*}{ 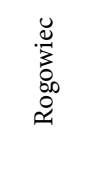 } & $\mathrm{A}$ & 2.57 & 1.29 & 1.36 & 49.71 & 5.29 & 6.84 & 8.43 & 10.91 \\
\hline & Ees & 2.71 & 1.38 & 1.40 & 48.99 & 1.60 & 2.21 & 18.51 & 25.58 \\
\hline & Bhfe & 2.62 & 1.41 & 1.46 & 46.24 & 3.33 & 4.70 & 23.95 & 33.80 \\
\hline & $\mathrm{C}$ & 2.55 & 1.60 & 1.66 & 37.13 & 3.69 & 5.91 & 16.96 & 27.15 \\
\hline \multirow{5}{*}{ 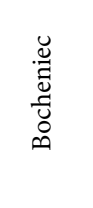 } & A & 2.41 & \multicolumn{7}{|c|}{ sample was not collected } \\
\hline & Ees & 2.54 & 1.14 & 1.18 & 55.27 & 3.51 & 3.99 & 13.48 & 15.31 \\
\hline & & 2.88 & 1.36 & 1.39 & 52.64 & 1.88 & 2.56 & 14.82 & 20.19 \\
\hline & Bhfe & 2.61 & 1.50 & 1.52 & 42.68 & 1.53 & 2.29 & 14.52 & 21.75 \\
\hline & $\mathrm{C}$ & 2.68 & 1.58 & 1.65 & 40.97 & 4.48 & 7.09 & 21.72 & 34.36 \\
\hline \multirow{6}{*}{ 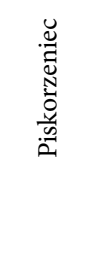 } & A & 2.49 & \multicolumn{7}{|c|}{ sample was not collected } \\
\hline & $\mathrm{AC}$ & 2.65 & 1.32 & 1.36 & 50.29 & 3.39 & 4.46 & 5.22 & 6.88 \\
\hline & $\mathrm{C}$ & 2.60 & 1.30 & 1.35 & 49.89 & 3.31 & 4.32 & 25.19 & 32.86 \\
\hline & & 2.62 & 1.68 & 1.77 & 35.82 & 5.23 & 8.78 & 17.91 & 30.08 \\
\hline & Mean & 2.61 & 1.41 & 1.46 & 46.33 & 3.39 & 4.83 & 16.43 & 23.53 \\
\hline & $S D$ & 0.11 & 0.16 & 0.17 & 6.35 & 1.31 & 2.13 & 6.10 & 9.43 \\
\hline
\end{tabular}

aVD - actual volumetric density $\left(\mathrm{g} \mathrm{cm}^{-3}\right)$; $\mathrm{BD}$ - bulk density $\left(\mathrm{g} \mathrm{cm}^{-3}\right)$; gAH - gravimetric actual humidity (\%); gCWC - gravimetric capillary water capacity (\%); P - total porosity (\%); $S D$ - standard deviation; tVD - temporary volumetric density $\left(\mathrm{g} \mathrm{cm}^{-3}\right)$; vAH - volumetric actual humidity (\%); vCWC - volumetric capillary water capacity (\%).

adsorption complex. These soils differ, however, in physical properties (cf. [27] and Tab. 2). The content of soil skeleton is inherently high in the mountain soils, and therefore their sorption capacity and $\mathrm{pH}$ are lower, which result from strong acidification caused by large amounts of plant litter.

A relatively high content of exchangeable cations recorded in Bocheniec is probably associated with the deposition of dust released by cement plants (Lafarge Cement Polska) situated $2 \mathrm{~km}$ away from the study site [28]. Higher content of cations $\mathrm{Ca}^{2+}$,
$\mathrm{Mg}^{2+}$ and $\mathrm{Na}^{+}$recorded at the site in Rogowiec in the humus horizon compared to lower soil horizons may be related to emission and deposition of dust from the Bełchatów Power Station. Relatively high saturation with alkaline cations may result from the presence of a combustion waste landfill site located $1 \mathrm{~km}$ west of the site [29]. At the time of dormancy, with no vegetation cover on the landfill surface, secondary dust emission occurs through deflation. Although the amounts of dust are small, due to depletion of sandy soil at this site, the "contamination" 
of the surface with combustion dust may induce the growth of P. vernalis. This thesis is supported by the results of Laitinen's experimental research [25], which revealed that ash admixture in forest soil devoid of moss cover and humus significantly enhances the germination and survival rates of $P$. vernalis seedlings. The obtained results indicate that the increased soil trophism in soil surface horizons is favorable to this species. However, the anthropogenic contamination reaching the soil together with precipitation causes the eutrophication of impoverished pine forest habitats. This results in the development of grass (e.g. Deschampsia flexuosa), which begins to dominate replacing oligotrophic and less competitive plant species [30].

The dust deposited in Rogowiec and Bocheniec probably also contributes to neutralization of acid reaction of surface soil horizons, and hence the lower values of the acidity coefficient recorded in humus horizons of these soils compared with the site in Piskorzeniec (Tab. 3). Also the results obtained by Kowalkowski and Świercz [31] confirmed the impact of limestone processing plants on changes in the soil acidity.

\section{Verification of the ecological indicator values}

As evidenced by the results of soil analysis, it is necessary to verify the ecological indicator values currently assigned to $P$. vernalis [22]. Similarly to previously introduced Ellenberg's indicator values [32], the edaphic indicators applied in Poland, and presented by Zarzycki et al. [33], are widely accepted and used to assess the habitat conditions. $P$. vernalis is, however, a species with a narrow phytosociological and ecological amplitude, growing in habitat conditions that differ in lowlands and mountains. Thus, it is necessary to distinguish between indicator values for mountain and lowland populations. In mountain areas, the species has been found on granite rocks with relatively steep slopes, at an altitude of 1670-2360 m a.s.l., where it grows in very shallow and poorly developed soils formed from granodiorites. These are moist soils (lithosols) with acid reaction [27,34-36]. As evidenced by this study, lowland sites of $P$. vernalis are distinguished by different soil-habitat conditions.
Based on the analysis of soil moisture content parameters at the lowland sites (very low values of moisture content and slightly higher capillary water capacity, both in relation to the total mass and the volume of soil; Tab. 2), it is proposed that the soil moisture indicator value of $W=3$ [22] should be replaced for $P$. vernalis by $W=2$. Also the species composition of phytocoenoses, and in particular the presence of terricolous lichens recorded in the communities with $P$. vernalis [24] weighs in favour of the lower coefficient value.

Mechanical composition of the soil at the lowland sites of P. ernalis (sandy soils, containing only a small amount of finer fractions with very homogenous density conditions; Tab. 1 and Tab. 2) weighs in favor of the granulometric index $(D)$ at the level of 3 , instead of the previous $D=3-1$.

The value of the soil acidity index $(R)$ for the lowland conditions, where $P$. vernalis grows on strongly acid and acid soils $-4<\mathrm{pH}<5$ (Tab. 3), should also be refined and changed to 1 .

Soils of $P$. vernalis habitats are impoverished in terms of organic matter content (Tab. 3), which corresponds to the $H$ index value of 1 compared to the previous value of 2 (representative of mineral-humus soils) [22].

The accepted range for temperature $(T)$, i.e. $1-4$ is also too broad. The value of $T=1$ should be accepted for mountain populations and $T=4$ for lowland populations growing in moderately warm climate conditions (to date, $P$. vernalis has not been found at sites represented by the temperature indicator value of 2 or 3 [24].

Indicator values for light $(L=4)$, continentality $(K=2)$ and fertility (trophic status; $\operatorname{Tr}=2$ ) [22] should remain the same.

\section{Recommendations on the active protection of $P$. vernalis in the lowland}

The reduction in the number and the size of $P$. vernalis populations is currently the most serious threat to the species preservation at the lowland sites [1]. Protection of the species involves certain measures aiming at both supplying the existing populations with specimens coming from the ex situ culture based on the seeds collected from plants, as well as from the

Tab. 3 Soil chemical properties within sites of P. vernalis.

\begin{tabular}{|c|c|c|c|c|c|c|c|c|c|c|c|c|}
\hline \multirow[b]{2}{*}{ Profile } & \multirow{2}{*}{$\begin{array}{c}\text { Soil } \\
\text { horizon }\end{array}$} & \multicolumn{2}{|c|}{ pH } & \multirow{2}{*}{$\begin{array}{c}\text { Corg } \\
\left(\mathbf{m g ~ k g}^{-1}\right)\end{array}$} & \multicolumn{4}{|c|}{ Exchangeable cations ( $\left.\mathrm{mg} \mathrm{kg}^{-1}\right)$} & \multicolumn{4}{|c|}{ Sorptive features $\left[\mathrm{cmol}(+) \mathrm{kg}^{-1}\right]$} \\
\hline & & in $\mathrm{H}_{2} \mathrm{O}$ & in $\mathrm{KCl}$ & & $\mathrm{Ca}^{2+}$ & $\mathbf{M g}^{2+}$ & $\mathrm{Na}^{+}$ & $\mathbf{K}^{+}$ & $\mathrm{Ha}$ & TEB & CEC & BS \\
\hline \multirow{4}{*}{ 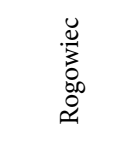 } & A & 6.20 & 5.60 & 1.10 & 3.20 & 0.19 & 0.08 & 0.06 & 4.75 & 3.90 & 8.65 & 45.09 \\
\hline & Ees & 4.40 & 4.40 & - & 0.20 & 0.02 & 0.02 & 0.03 & 2.50 & 0.60 & 3.10 & 19.35 \\
\hline & Bhfe & 5.00 & 4.40 & 0.38 & 0.10 & $<0.02$ & 0.02 & 0.03 & 4.63 & 0.90 & 5.53 & 16.29 \\
\hline & $\mathrm{C}$ & 5.20 & 4.60 & - & $<0.1$ & $<0.02$ & 0.02 & 0.02 & 1.75 & 0.40 & 2.15 & 18.60 \\
\hline \multirow{4}{*}{ 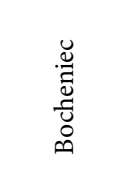 } & $\mathrm{A}$ & 5.50 & 5.10 & 3.89 & 7.80 & 0.19 & 0.20 & 0.14 & 11.25 & 11.70 & 22.95 & 50.98 \\
\hline & Ees & 6.20 & 4.60 & - & 1.50 & 0.04 & 0.05 & 0.05 & 4.50 & 1.70 & 6.20 & 27.42 \\
\hline & & 5.20 & 4.20 & - & 0.40 & $<0.02$ & 0.02 & 0.03 & 4.38 & 0.50 & 4.88 & 10.26 \\
\hline & Bhfe & 5.00 & 4.20 & 0.64 & 0.20 & $<0.02$ & 0.02 & 0.02 & 3.75 & 0.10 & 3.85 & 2.60 \\
\hline \multirow{5}{*}{ 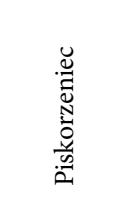 } & $\mathrm{C}$ & 4.80 & 4.50 & - & $<0.1$ & $<0.02$ & 0.02 & 0.02 & 2.50 & 0.50 & 3.00 & 16.67 \\
\hline & $\mathrm{A}$ & 4.10 & 3.20 & 2.70 & 0.50 & 0.06 & 0.04 & 0.09 & 19.75 & 0.50 & 20.25 & 2.47 \\
\hline & $\mathrm{AC}$ & 4.80 & 4.30 & 0.43 & $<0.01$ & $<0.02$ & 0.02 & 0.03 & 5.50 & 0.30 & 5.80 & 5.17 \\
\hline & $\mathrm{C}$ & 4.70 & 4.10 & - & $<0.01$ & $<0.02$ & 0.03 & 0.05 & 6.38 & 0.70 & 7.08 & 9.89 \\
\hline & & 4.70 & 4.40 & - & $<0.01$ & $<0.02$ & 0.02 & 0.03 & 3.00 & 0.20 & 3.20 & 6.25 \\
\hline \multicolumn{2}{|c|}{ Mean for A horizons } & 5.27 & 4.63 & 2.56 & 3.83 & 0.15 & 0.11 & 0.10 & 11.92 & 5.37 & 17.28 & 32.85 \\
\hline \multicolumn{2}{|c|}{$S D$ for A horizons } & 1.07 & 1.27 & 1.40 & 3.69 & 0.08 & 0.08 & 0.04 & 7.52 & 5.74 & 7.60 & 26.47 \\
\hline \multicolumn{2}{|c|}{ Mean for deeper horizons } & 5.00 & 4.37 & 0.48 & 0.48 & 0.03 & 0.02 & 0.03 & 3.89 & 0.59 & 4.48 & 13.25 \\
\hline \multicolumn{2}{|c|}{$S D$ for deeper horizons } & 0.49 & 0.17 & 0.14 & 0.58 & 0.01 & 0.01 & 0.01 & 1.46 & 0.46 & 1.64 & 7.71 \\
\hline
\end{tabular}

BS - base saturation rank; CEC - cation exchange capacity; Ha - hydrolytic acidity; SD - standard deviation; TEB - total exchangeable bases. 
species introduction at new sites. Such measures have already been undertaken in the State Forests of the Forest Division of Kaliska (Tuchola Forest), where local populations of $P$. vernalis are replenished by plants obtained from seeds [37].

The results of soil analysis presented in this paper should be accounted for in the planning and efficient implementation of $P$. vernalis active protection in lowland Poland. When selecting potential sites for reintroduction and introduction of the pasqueflower, one should take into account the fact that the species prefers poor sandy soils, almost free of finer (clayey) material, developed from the deposits of glacial or glaciofluvial origin. They should be podzolic soils with a small content of humus, and acid or strongly acid reaction throughout the profile, and at the same time dry with moderate porosity and small capillary water capacity.

Furthermore, because of the low competitiveness of $P$. vernalis towards other plant species, active protection measures should be applied at the existing sites that would reduce the development of competitive species. The availability of microhabitats with no moss and lichen cover is yet another factor required for regeneration of $P$. vernalis populations in natural conditions [24,25].

The presence of arbuscular mycorrhizal fungi is conducive to vegetation of $P$. vernalis in oligotrophic coniferous forest habitats. The fungi increase the resistance of plants to abiotic and biotic stress [38], and enable the species to colonize new sites [39]. The examination of 7-month-old juvenile seedlings of $P$. vernalis (in potted culture) obtained from seeds coming from the site in Rogowiec revealed a very high degree of root colonization by arbuscular fungi [24]. The absolute abundance of arbuscules was $90 \%$ and the mycorrhizal frequency - as much as $98 \%$ of cortex cells. Seeds obtained from natural sites are therefore already "equipped" with a proper set of mycorrhizal fungi. At the time of fruiting, however, plants should have access to exposed sandy soils enriched with a small amount of organic matter. During germination and the growth of $P$. vernalis seedlings, a temporary increase in the soil moisture is also recommended [24].

In the primeval forest landscape, the best conditions for the growth of $P$. vernalis are probably in the open pine forests [40], in places of local, natural disturbances (i.e. windthrow sites, burnt areas). Nowadays, anthropogenic disturbance resulting in thinning of the forest canopy (patch felling, shelterwood cutting) or exposed soil (mechanical destruction of the vegetation cover during silvicultural treatments) is a factor conducive to the preservation of sites within the forest plant communities. However, because of the risk of destroying the $P$. vernalis population, it is necessary to monitor all the forestry work carried out within a site. Effective species protection requires additional legal stipulations. It is proposed that similarly to Pulsatilla patens protected in Poland within the framework of NATURA 2000 [41], P. vernalis should be included on the list of species that require a protection zone around a site.

Guidelines and suggestions included in this paper should significantly improve the effectiveness of Pulsatilla vernalis protection in the lowland areas of Poland.

\section{Acknowledgments}

We are grateful to anonymous reviewers and to Associate Editor for their helpful comments during the preparation of this manuscript. This study was financially supported by Department of Geobotany and Plant Ecology, University of Łódź.

\section{Authors' contributions}

The following declarations about authors' contributions to the research have been made: study conception: AG; field research: AG, AN; soil laboratory analysis AN; analyzed the data and wrote the paper: $\mathrm{AG}, \mathrm{AN}, \mathrm{BW}$.

\section{References}

1. Grzyl A, Ronikier M. Pulsatilla vernalis (L.) Mill. (Ranunculaceae) in the polish lowlands: contribution to the assessment of current population resources of a strongly declining species. Pol Bot J. 2011;56(2):185-194.

2. Wójtowicz W. Pulsatilla vernalis (L.) Mill. - sasanka wiosenna. In: Kaźmierczakowa R, Zarzycki K, editors. Polish red data book of plants. Pteridophytes and flowering plants. Cracow: W. Szafer Institute of Botany, Polish Academy of Sciences; 2001. p. 64-65.

3. Zarzycki K, Szeląg Z. Red list of the vascular plants in Poland. In: Mirek Z, Zarzycki K, Wojewoda W, Szeląg Z, editors. Red list of plants and fungi in Poland. Cracow: W. Szafer Institute of Botany, Polish Academy of Sciences; 2006. p. 9-20.

4. Rozporządzenie Ministra Środowiska z dnia 5 stycznia 2012 r. w sprawie ochrony gatunkowej roślin. 2012.

5. Zając M, Zając A. The geographical elements of native flora of Poland. Cracow: Laboratory of Computer Chorology, Institute of Botany, Jagiellonian University; 2009.

6. Pawłowski B. Die geographischen Elemente und die Herkunft der Flora der subnivalen Vegetationsstufe im Tatra-Gebirge. Bull Int Acad Pol Sci Cl Sci Math Ser B Sci Nat. 1928;:161-202.

7. Pawłowska S. Charakterystyka statystyczna i elementy flory polskiej. In: Szafer W, Zarzycki K, editors. Szata roślinna Polski. Warsaw: Polish Scientific Publishers PWN; 1977. p. 127-206. (vol 1).

8. Jalas J, Suominen J, editors. Nympheaceae to Ranunculaceae. In: Atlas florae Europaeae. Distribution of vascular plants in Europae. Helsinki: Suomalaisen Kirjallisuunden Kirjapaino Oy; 1989. (vol 8).

9. Korneck D, Schnittler M, Vollmer I. Rote Liste der Farn- und Blütenpflanzen (Pteridophyta et Spermatophyta) Deutschlands. In: Ludvig G, Schnittler M, editors. Rote Liste gefährdeter Pflanzen Deutschlands. Schriftenreihe für Vegetationskunde. Bonn: Bayerische Landesamt für Umweltschutz; 1996. p. 21-187. (vol 28).

10. Čeřovský J. Pulsatilla vernalis (L.) Mill. In: Čeřovský J, Feráková V, Holub J, Maglocký Š, Procházka F, editors. Červená kniha ohrozených a vzácnych druhov rastlín a živočichov SR a ČR. Vyššie rastliny. Bratislava: Priroda; 1999. p. 303. (vol 5).

11. Wind P. Fredede arter i Danmark 4. Urt. 1993;17:58-63.

12. Lindell T. Pulsatilla Mill. In: Jonsell B, Karlsson T, Agestam M, Bygren N, Hultgård UM, Persson E, editors. Flora Nordica. Stockholm: The Royal Swedish Academy of Sciences; 2001. p. 305-310. (vol 2).

13. Åström S, Stridh B. Mosippa - årets växt 2002. Bot Sven Tidskr. 2003;97:117-126

14. Simačev VI. Prostrel vesennij Pulsatilla vernalis (L.) Mill. In: Noskov GA, editor. Red data book of nature of Leningrad region. Plants \& fungi. Saint Petersburg: Mir i semya-95 Publ; 2000. p. 264-264. (vol 2).

15. Simačev VI. Žiznennyj cikl i vozrostnaâ struktura cenopopulâcij Pulsatilla vernalis (L.) Mill. w leningradskoj obłasti. Bot Żurn. 1978;7:1016-1025.

16. Adler W, Oswald K, Fischer R. Exkursionflora von Österreich. Stuttgart: Verlag Eugen Ulmer; 1994.

17. Parfienov V, Lâkavičûs A, Kozłovskaâ N, Vynaew G, Ânkâvičene R, Balâvičene U, et al. Redkie i isčezaûŝie vidy rastenij Belorussii i Litvy. Minsk: Nauka i Technika; 1987.

18. Ronikier M, Costa A, Aguilar JF, Feliner GN, Küpfer P, Mirek Z. Phylogeography of Pulsatilla vernalis (L.) Mill. (Ranunculaceae): chloroplast DNA reveals two evolutionary lineages across central Europe 
and Scandinavia. J Biogeogr. 2008;35(9):1650-1664. http://dx.doi. org/10.1111/j.1365-2699.2008.01907.x

19. Zając A, Zając M, editors. Distribution atlas of vascular plants in Poland. Cracow: Laboratory of Computer Chorology, Institute of Botany, Jagiellonian University; 2001.

20. Ronikier M, Grzyl A, Wójtowicz W. Pulsatilla vernalis (L.) Mill. - sasanka wiosenna. In: Kaźmierczakowa R, Zarzycki K, editors. Polish red data book of plants. Pteridophytes and flowering plants. Cracow: W. Szafer Institute of Botany, Polish Academy of Sciences; in press.

21. Ellenberg H, Weber HE, Düll R, Wirth V, Werner W, Paulissen D. Zaigerwerte von Pflanzen in Mitteleuropa. Scr Geobot. 1991;18:1-248.

22. Zarzycki K, Trzcińska-Tacik H, Różański W, Szeląg Z, Wołek J, Korzeniak U. Ecological indicator values of vascular plants of Poland. Cracow: W. Szafer Institute of Botany, Polish Academy of Sciences; 2002. (vol 2).

23. Matuszkiewicz W. Przewodnik do oznaczania zbiorowisk roślinnych Polski. Warsaw: Polish Scientific Publishers PWN; 2005. (vol 3).

24. Grzyl A. Biologia i ekologia izolowanych populacji sasanki wiosennej Pulsatilla vernalis (L.) Mill. na wschodnich krańcach jej zasięgu w Polsce [PhD thesis]. Łódź: Univeristy of Łódź; 2012.

25. Laitinen $P$. The effects of forest fires on the persistence of Pulsatilla vernalis (L.) Mill. [PhD thesis]. Jyväskylä: University of Jyväskylä; 2008.

26. Systematyka gleb Polski. Rocz Glebozn. 2011;62(3):1-142.

27. Piękoś-Mirkowa H, Mirek Z, Miechówka A. Distribution and habitats of Pulsatilla vernalis (L.) Mill. in the Tatra Mountains. Oecologia Mont. 2000;9(1-2):19-23.

28. Świercz A. Wpływ emisji cementowni Lafarge Cement Polska w Małogoszczy (woj. świętokrzyskie) na wybrane właściwości gleb bielicowordzawych oraz na zawartość metali ciężkich w igliwiu i korze sosny zwyczajnej. In: Miler AT, editor. Kształtowanie i ochrona środowiska leśnego. Poznań: Poznań University of Life Sciences Press; 2003. p. 428-438.

29. Kobus A, Janigacz D. Pomiary opadu pyłu wokół składowiska odpadów paleniskowych "Bagno Lubień" oraz wzdłuż trasy suchego odpopielania i miejsca składowania mieszaniny nadkładu i popiołu KWB "Bełchatów" 1999. Gliwice: Zakład Pomiarowo-Badawczy Energetyki Energopomiarowej; 2000.

30. Danielewicz W, Pawlaczyk P. Sosnowy bór chrobotkowy (Cladonio-Pinetum i chrobotkowa postać Peucedano-Pinetum). In: Herbich J, editor. Poradnik ochrony siedlisk i gatunków Natura 2000 - podręcznik metodyczny. Lasy i bory. Warsaw: Ministry of the Environment; 2004. p. 291-296. (vol 5).

31. Kowalkowski A, Świercz A. Zmiana kwasowości gleb leśnych pod wpływem emisji przemysłu wapienniczo-cementowego w zlewni rzeki Bobrzyczki. Monit Śr Przyr. 1993;1/93:109-115.

32. Ellenberg H. Zeigerwerte der Gefäßpflanzen Mitteleuropas. Scr Geobot. 1974;9:1-97.

33. Zarzycki K. Ekologiczne liczby wskaźnikowe roślin naczyniowych Polski. Cracow: W. Szafer Institute of Botany, Polish Academy of Sciences; 1984.

34. Pawłowska S. Sasanki. Chrońmy Przyr Ojcz. 1951;(3/4):3-18.

35. Piękoś-Mirkowa H, Miechówka A. Rozmieszczenie rzadkich taksonów roślin naczyniowych na obszarze Tatr. Chrońmy Przyr Ojcz. 1999;55(1):74-79.

36. Mirek Z, Piękoś-Mirkowa H, Ronikier M. Sasanka wiosenna - Pulsatilla vernalis (L.) Mill. In: Mirek Z, Piękoś-Mirkowa H, editors. Czerwona księga Karpat Polskich. Rośliny naczyniowe. Cracow: W. Szafer Institute of Botany, Polish Academy of Sciences; 2008. p. 348-350.

37. Nawrocka-Grześkowiak U, Frydel K. Stanowiska sasanki wiosennej [Pulsatilla vernalis (L.) Miller] w Nadleśnictwie Kaliska. Spring anemone [Pulsatilla vernalis (L.) Miller] sites in Forest Inspectorate Kaliska. Zarządzanie Ochr Przyr. 2013;6:77-84.

38. Azcón-Aguilar C, Jaizme-Vega MC, Calvet C. The contribution of arbuscular mycorrhizal fungi to the control of soil-borne plant pathogens. In: Gianinazzi S, Schüepp H, Barea JM, Haselwandter K, editors. Mycorrhizal technology in agriculture. Basel: Birkhäuser Basel; 2002. p. 187-197. http:// dx.doi.org/10.1007/978-3-0348-8117-3_15

39. Moora M, Öpik M, Sen R, Zobel M. Native arbuscular mycorrhizal fungal communities differentially influence the seedling performance of rare and common Pulsatilla species. Funct Ecol. 2004;18(4):554-562. http://dx.doi. org/10.1111/j.0269-8463.2004.00876.x

40. Szafer W. Szata roślinna Polski niżowej. In: Szafer W, Zarzycki K, editors. Szata roślinna Polski. Warsaw: Polish Scientific Publishers PWN; 1977. p. 17-188.

41. Rozporządzenie Ministra Środowiska, $z$ dnia 9 sierpnia 2012 r. zmieniające rozporządzenie w sprawie siedlisk przyrodniczych oraz gatunków będących przedmiotem zainteresowania Wspólnoty, a także kryteriów wyboru obszarów kwalifikujących się do uznania lub wyznaczenia jako obszary Natura 2000. 2012. 